\title{
Validitas Referensi
}

\author{
Ismail Suardi Wekke \\ Pasca Sarjana Sekolah Tinggi Agama Islam Negeri (STAIN) Sorong \\ Email: iswekke@gmail.com
}

\begin{abstract}
ABSTRAK
Artikel ini mengemukakan keperluan akan pentingnya pengecekan sebuah kepustakaan dengan memperhatikan validitas (sahih) sebuah bacaan. Sekaligus, diperlukan pula unsur otoritas untuk menyampaikan maklumat tersebut. Keduanya tidak bisa dipisahkan sama sekali, sehingga akan tercipta bangunan ilmu pengetahuan yang kokoh atas bentukan rujukan yang berkesinambungan.
\end{abstract}

Kata Kunci: validitas, sahih, kepustakaan

\section{Pendahuluan}

Di saat menggunakan sebuah referensi, tidak semua kepustakaan dapat digunakan begitu saja. Dengan melimpahruahnya maklumat yang ada saat ini, memungkinkan sebuah informasi hadir di tengah kalangan ilmuwan tak terbatas. Namun informasi tersebut bisa jadi sama sekali tidak mengandung kebenaran ilmiah. Bahkan bisa jadi justru merupakan informasi yang diadaadakan. Sebagaimana dalam narasi Harun Yahya yang menunjukkan maklumat yang menggugah. Sebaliknya, informasi itu justru tidak mengandung aspek keilmiahan sama sekali. Hanya sekadar sebagai propaganda (Riexinger, 2008). Karena direkonstruksi dengan menggugah emosi sehingga cenderung menjadi debat (Guessoum, 2015) disebut juga dengan pseudo-science (Sayin \& Kence, 1999), theoscientography (Bigliardi, 2014).

Terkadang ketegangan antara science dan agama dieksplorasi untuk menjadi diskursus yang mengguncang emosi (Edis, 2008). Bahkan terdapat generasi yang memutuskan untuk membuat garis demarkasi antara harmoni Islam dan sains yang sudah tercipta di era sebelumnya (Bigliardi, 2014). Padahal antara Islam sebagai wahyu dan ilmu pengetahuan sebagai hasil empiris tidak akan pernah bertentangan sama sekali. Secara perlahan, jika terdapat sebuah informasi yang bertentangan baik dengan wahyu maupun empiris-positivistik, akan ditolak dan ditemukan kelemahannya. Sehingga tidak memenuhi unsur untuk disebut bagian dari ilmu pengetahuan. Zaman demi zaman, hanya akan menerima maklumat yang sesuai dengan kedua hal tersebut, wahyu dan empiris-positivistik.

Kasus demi kasus akan memperkuat bangunan teoritis keilmuan. Namun ketika kasus itu justru didukung oleh rujukan yang tidak valid, maka akan memberikan tambahan kasus dalam bangunan teori tetapi justru bukan mengukuhkan informasi. Justru informasi yang membuat "bangunan" keropos. Untuk itu diperlukan konsistensi informasi untuk pengembangan konstruksi keilmuan (Chaffee \& Roser, 1986). Untuk membangun kepakaran diperlukan 
konsistensi dan kelengkapan (Nguyen, Perkins, Laffey \& Pecora, 1985; Walker, Thorne, Sinclair, Thapa, Wood \& Subba, 1999). Tidak memungkinkan kepakaran terbentuk secara tibatiba. Terkait juga dengan relevansi secara kontekstual (Fabrigar, Petty, Smith \& Crites Jr, 2006). Perkembangan ilmu atau kadang disebut juga dengan ilmu pengetahuan sesungguhnya merupakan evolusi sejak zaman Yunani sampai saat ini. Sehingga tidak memungkinkan keberadaan ilmu pengetahuan memunculkan revolusi secara tiba-tiba. Dengan demikian kekukuhan bangunan ilmu pengetahuan harus berpijak pada hasil yang sudah dicapai pada era sebelumnya.

\section{Rujukan yang Sahih dan Otoritas}

Ketidaktepatan rujukan akan mengakibatkan kekacauan dan ketidakteraturan ilmu pengetahuan. Jangan sampai informasi yang dirujuk sesungguhnya tidak sahih dan bahkan tidak memiliki otoritas keilmuan untuk dirujuk. Bahkan jurnal sekalipun tetap perlu diuji validitas. Bukan berarti bahwa sebuah informasi yang ada dalam jurnal otomatis sudah valid. Untuk itu, dewan penyunting secara berkala melakukan audit untuk menguji kesahihan sebuah informasi yang sudah terbit sekalipun. Dewan editor akhirnya memutuskan untuk melakukan tindakan restraksi artikel karena ditemukan kesilapan akademik, termasuk pada terjadinya penerbitan ganda (Wager \& Williams, 2011). Sejak awal, editor jurnal yang berimpak tinggi mengemukakan kebijakan tentang restraksi pada kondisi yang tidak menepati proses akademik dan terjadinya pelanggaran pada prinsip-prinsip ilmiah (Atlas, 2004).

Sebagai contoh dalam kasus berikut. Affandi, Korver, Geurts \& Bennink (1999) dan juga dalam artikel yang lain Suherman, Affandi \& Korver (1999) memublikasikan tentang kontrasepsi 200 perempuan Indonesia. Melalui surat ke editor, Rekers \& Affandi (2004) mengemukakan ketidaksahihan artikel sehingga perlu dilakukan tindakan restraksi. Contoh berikutnya karya yang ditulis Mimi, Nazer, Siebel \& Van der Zaag (2010) sejak awal artikel menuliskan Israel. Semasa perbaikan akhir justru mengubah kata Israel ke kata historical Palestine. Kekeliruan disadari setelah terbit, sehingga akhirnya artikel perlu direstraksi. Terakhir, Suparman (2016a) menulis artikel yang sebelumnya sudah terbit di sebuah jurnal dengan judul yang berbeda tetapi justru dengan konten yang sama (Suparman, 2016b). Kasus tersebut membuktikan bahwa artikel yang terbit di jurnal sekalipun, tidak serta merta dapat diterima begitu saja jika tidak memenuhi unsur keilmiahan. Dalam proses berikutnya, jika ditemukan ada pelanggaran akademik, maka artikel tersebut dapat dinyatakan dengan status restraksi dan seluruh sitasi yang sudah didapatkan langsung dihapus. 
Budd, Sievert, Schultz \& Scoville (1999) menunjukkan 235 artikel yang diretraksi karena dua masalah. Kesalahan tersebut terkait dengan metode, sampel, dan adanya sampel yang terkontaminasi. Faktor kedua terjadinya kesilapan penerapan metode selama proses penelitian. Ini menjadi signal bahwa sekalipun artikel sudah terbit, tetap saja data dicabut penerbitan dan semua sitasi yang mengiringinya. Sebab akan membawa pada kesimpulan yang keliru jika dibiarkan seperti itu. Kualitas proses penelitian menjadi bagian yang tidak terpisahkan dalam proses penerbitan. Sehingga ketika kualitas penelitian bermasalah, akan berdampak pada kualitas artikel (Glasziou, Vandenbroucke \& Chalmers, 2004). Termasuk dalam penerapan secara operasional langkah-langkah pendekatan penelitian (Mays \& Pope, 2000).

Salah satu rujukan primer yaitu paten. Penggunaan paten sebagai rujukan utama karena sudah melalui proses review yang berjenjang. Bahkan sebuah informasi yang tersaji dalam paten digunakan untuk pengembangan teknologi (Verbeek, Debackere, Luwel, Andries, Zimmermann \& Deleus, 2002). Dengan demikian, ketika sebuah paten digunakan sebagai referensi dalam penulisan artikel, maka sumber yang dirujuk sudah memiliki informasi yang otoritatif. Perkembangan teknologi seiring dengan pengembangan sains. Temuan-temuan penelitian melalui sains dijadikan sebagai dasar dalam mengembangkan sebuah teknologi. Sitasi terhadap publikasi dan paten menjadi petunjuk bahwa teknologi dikembangkan dengan adanya penelitian intensif sebelumnya (Meyer, 2000). Namun dengan tidak meninggalkan literatur dasar (Carpenter, Cooper \& Narin, 1980). Bagaimanapun, penggunaan literatur dasar menjadi rujukan utama dalam pengembangan sains. Sehingga tidak dapat ditinggalkan sama sekali. Perkembangan sains dan teknologi bukan berarti meninggalkan sama sekali ilmu sosial. Dapat dilihat dalam nanoteknologi yang terlihat dalam ranah kajian sains dan teknologi. Bidang ini juga mendapat sumbangsih dari kajian ilmu sosial dalam bentuk interdisipliner (Huang, Notten\& Rasters, 2011).

Untuk mengembangkan inovasi, maka makalah konseptual yang dirancang para teknisi sepenuhnya mengacu kepada sitasi yang berasal dari artikel dan paten (Jaffe \& Trajtenberg, 2002). Dari sini dapat terlihat bahwa keberadaan artikel dan paten tidak bisa dipisahkan dalam perkembangan keilmuan dan teknologi. Ketika sebuah informasi tidak sahih, maka bisa jadi akan memberikan haluan yang salah arah bagi pengembangan ilmu pengetahuan. Sebab apa yang sudah dirujuk sejak awal merupakan informasi yang keliru.

Untuk itu, diperlukan wawasan kesarjanaan (scholarship). Di saat menemukan maklumat tidak serta merta diterima atau ditolak sama sekali. Tetapi memerlukan kecermatan dan ketelitian terlebih dahulu. Saya menyebutnya sebagai "verifikasi internal" dari pembaca. Sehingga diputuskan bahwa referensi yang dibaca tersebut, layak untuk digunakan sebagai rujukan dalam 
aktivitas akademik. Setelah melalui tahapan ini, maka informasi yang diterima tersebut dapat dijadikan sebagai rujukan. Terlebih lagi kalau informasi berasal dari media massa yang dikhususkan untuk menyebarluaskan maklumat kepada publik. Bisa saja makluma tersebut hanya diverifikasi oleh editor berita tanpa melalui proses pengecekan mendalam.

\section{Penutup}

Penggunaan sebuah referensi perlu mengecek terlibih dahulu kriteria sebuah informasi. Sehingga tidak menjadi informasi yang hanya diperoleh secara sepihak. Proses pengembangan ilmu pengetahuan melalui proses evolusi yang memungkinkan adanya kadaan yang sama dari waktu ke waktu. Sehingga dalam proses penemuan ilmu pengetahuan tidak ditemukan sebuah kejadian yang surprise. Semuanya memiliki landasan dan pengalaman di era sebelumnya.

\section{Daftar Pustaka}

Affandi, B., Korver, T., Geurts, T. P., \& Bennink, H. J. C. (1999). A pilot efficacy study with a single-rod contraceptive implant $\left(\right.$ Implanon $\left.{ }^{\circledR}\right)$ in 200 Indonesian women treated for $\leq 4$ years. Contraception, 59(3), 167-174.

Atlas, M. C. (2004). Retraction policies of high-impact biomedical journals. Journal of the Medical Library Association, 92(2), 242.

Bigliardi, S. (2014). The contemporary debate on the harmony between Islam and science: Emergence and challenges of a new generation. Social Epistemology, 28(2), 167-186.

Bigliardi, S. (2014). Who's Afraid of Theoscientography? An Interpretative Hypothesis on Harun Yahya. Zygon®, 49(1), 66-80.

Budd, J. M., Sievert, M., Schultz, T. R., \& Scoville, C. (1999). Effects of article retraction on citation and practice in medicine. Bulletin of the Medical Library Association, 87(4), 437.

Carpenter, M. P., Cooper, M., \& Narin, F. (1980). Linkage between basic research literature and patents. Research Management, 23(2), 30-35.

Chaffee, S. H., \& Roser, C. (1986). Involvement and the consistency of knowledge, attitudes, and behaviors. Communication research, 13(3), 373-399.

Edis, T. (2008). Modern science and conservative Islam: An uneasy relationship. In Science, worldviews and education (pp. 237-255). Springer, Dordrecht.

Fabrigar, L. R., Petty, R. E., Smith, S. M., \& Crites Jr, S. L. (2006). Understanding knowledge effects on attitude-behavior consistency: The role of relevance, complexity, and amount of knowledge. Journal of Personality and Social Psychology, 90(4), 556.

Glasziou, P., Vandenbroucke, J., \& Chalmers, I. (2004). Assessing the quality of research. Bmj, $328(7430), 39-41$.

Guessoum, N. (2015). Islam and Science: The Next Phase of Debates: with Nidhal Guessoum,"Islam and Science: The Next Phase of the Debates"; and Anindita Niyogi Balslev, “'Science-Religion Samvada' and the Indian Cultural Heritage.”. Zygon®, 50(4), 854-876.

Huang, C., Notten, A., \& Rasters, N. (2011). Nanoscience and technology publications and patents: a review of social science studies and search strategies. The Journal of Technology Transfer, 36(2), 145-172.

Jaffe, A. B., \& Trajtenberg, M. (2002). Patents, citations, and innovations: A window on the knowledge economy. MIT press.

Mays, N., \& Pope, C. (2000). Assessing quality in qualitative research. Bmj, 320(7226), 50-52. 
Meyer, M. (2000). Does science push technology? Patents citing scientific literature. Research policy, 29(3), 409-434.

Mimi, Z., Nazer, D., Siebel, M., \& Van der Zaag, P. (2010). Optimizing irrigation water use in the West Bank, Palestine. Agric Water Manage, 97, 339-345.

Nguyen, T. A., Perkins, W. A., Laffey, T. J., \& Pecora, D. (1985, August). Checking an Expert Systems Knowledge Base for Consistency and Completeness. In IJCAI (Vol. 85, No. 1, pp. 375-378).

Rekers, H., \& Affandi, B. (2004). Letter to the editor. Contraception, 70(5), 433.

Riexinger, M. (2008). Propagating Islamic creationism on the internet. Masaryk UJL \& Tech., 2, 99.

Sayin, U., \& Kence, A. (1999). Islamic scientific creationism: a new challenge in Turkey. Reports of the National Center for Science Education, 19(6), 18-20.

Suherman, S. K., Affandi, B., \& Korver, T. (1999). The effects of implanon ${ }^{\circledR}$ on lipid metabolism in comparison with norplant ${ }^{\circledR}$. Contraception, 60(5), 281-287.

Suparman, S. (2016a). RETRACTED: Implementation of reversible jump MCMC algorithm to segment the piecewise Polynomial Regression. International Journal of Advances in Intelligent Informatics, 2(2), 88-93.

Suparman, S. (2016b). Segmentation of Piecewise Polynomial Regression Model by Using Reversible Jump MCMC Algorithm. International Journal of Mathematical, Computational, Physical, Electrical and Computer Engineering, 10(5) 232-235.

Verbeek, A., Debackere, K., Luwel, M., Andries, P., Zimmermann, E., \& Deleus, F. (2002). Linking science to technology: Using bibliographic references in patents to build linkage schemes. Scientometrics, 54(3), 399-420.

Wager, E., \& Williams, P. (2011). Why and how do journals retract articles? An analysis of Medline retractions 1988-2008. Journal of medical ethics, 37(9), 567-570.

Walker, D. H., Thorne, P. J., Sinclair, F. L., Thapa, B., Wood, C. D., \& Subba, D. B. (1999). A systems approach to comparing indigenous and scientific knowledge: consistency and discriminatory power of indigenous and laboratory assessment of the nutritive value of tree fodder. Agricultural systems, 62(2), 87-103. 